\title{
THE DEVELOPMENT OF FEATURE RADIO AS A MODEL IN MAKING RADIO BROAD- CASTING PRODUCT FOR ENGLISH DEPARTMENT STUDENTS OF STATE POLYTECHNIC OF PADANG
}

\author{
Sumira, Nini Wahyuni \\ Politeknik Negeri Padang \\ sumiradoano@gmail.com, ni2_wa@yahoo.com
}

\begin{abstract}
This Research and Development (RED) study discussed about the development of feature radio as the model in making radio broadcasting product for English Department students of State Polytechnic of Padang. The aims of this research is to develop an appropriate model of feature radio that can be used as the standard model in conducting final project. The development was carried out through several steps, namely; needs analysis, product development, product validation, and revision. The needs analysis data were taken from syllabus, academic data, and interview. Meanwhile, the product validation were taken from experts' judgment. The data were collected through analyzing syllabus, conducting interviews, and giving questionnaires. The result of this research is a model of feature radio.
\end{abstract}

Keywords: Feature radio, Research and Development, Pre-production, Production, Post Production

\section{Introduction}

Facing the globalization era, vocational college has to formulate their teaching and learning process as a place to train their students to be ready working in a work field. Therefore, the vocational students have to be equipped with special skills during their study. In State Polytechnic of Padang, especially for English Department, students are provided with two additional skills, namely; translation and broadcasting. The students are required to produce translation or broadcasting product as their final project. For translation, the students have to produce translation result in form of texts book, story book, novel, booklet, brochure, etc.Meanwhile, for the students who interested in broadcasting area, they can choose the product in two formats; audio visual/movie or audio/ radio in form of feature, documentary, advertorial, etc.

In radio broadcasting, the students learn how to produce various radio program, one of them is feature. Feature is a news product which discusses a particular theme that contain a human interest and it can be a documentary. It has a high value and it has selling point if it is packaged in a good and professional form. Furthermore, the students who interested in making radio feature as their final project can offer or sell their product to company or radio industry after their gradu- ate.

However, the number of students who is interested in conducting feature radio as their final project is only a few. Based on the academic data of English Department, in academic year 2014/2015, there were three of 49 students who chose radio broadcasting as their final project. Meanwhile, in academic year 2015/ 2016, the number decrease significantly become one from 48 students. Moreover, bbased on the discussion with some graduate students of English Department, it wasfound that they did not want to choose radio broadcasting as their final project because they said that there is no model of standard radio feature and they were not sure the steps or procedures in producing feature radio.

Generally, producing radio broadcasting product especially feature radio is easier than making TV broadcasting product. It can be seen from the time spending andthe pproductioncost. To make a feature radio, students can do it by themselves because they do not need crew as producing TV broadcasting product. In addition, the students do not need much money to buy or rent some tools such as camera, tripod, lighting, and others properties as movies production. Especially, for feature radio, the students just need recorder and they 
can use their smart-phone as the production tool. Consequently, if they produce radio format, they can graduate in time ( 3 years).

Realizing the problems, it is needed to developa standardize reference and model as guidance for the students in producing feature radio as their final project. It is hoped that the feature radio that has been made can be a model in creating further radio broadcasting product. Thus, the number of students who interested in feature radio will increase and automatically the product of the students' project will be more diverse.

Feature is a combination of news, interviews, editor reviews, back sound, and wild tracking. It is a radio news product which has duration 10-30 minutes. As a non-factual news that is timeless, feature informs an event, a situation, or aspect of life. According to Fachruddin (2014), feature is kind of news which discusses about a main topic and shows in some different views like details, critically, and creatively. Feature is different than news because it more emphasizes to a unique story which make the viewer interest to watch without ignoring the important information. In addition, feature can give a major effect to the viewer/ reader/ listener and it delivers with long narration.

Mohamad (cited in Lesmana 2017) states that feature is a creative article that is subjective, and it used to make the reader become happy and get the information. The characteristics of feature are giving important material and aiming to entertain and educate. There are some elements of feature radio such as creativity, informative, entertain, timeless, and subjectivity.

Creative means that the feature writing allows the reporter to make a story, but it should be accurate and it enables the journalist creating a story because it is different from hard news. The journalist can find the idea of feature after doing a research.

Informative means that feature give information about situation or aspect of life.

Then, entertain means that feature can be an alternatives program besides reality shows, drama, and other. The journalist can create a colorful stories in order to get the felling of event.

Timeless means that feature can be reply anytime and repeatedly. It is non-factual news thus the information can be used anytime.

Subjectivity means that the journalist can use her/ his subjectivity in making feature. It can be written in form of " $\mathrm{I}$ " thus the journalist can put their emotions and thought.

There are many kind of features, such as profile, history, adventure, seasonal, science, travelogue, food, and human interest feature. In making the feature, there are some procedures that should be follows. As state by Fachruddin (2014), the process of making feature can be divided into three categories, namely; pre-production, production, and post production.

Pre-production. It is a plan and guidance detail before doing production. There are several activities can be done such as finding the idea, topic, and angle/ perspective, preparing the budget, making the wish list, finding the informant, and preparing the tools.

Production. In producing a feature, there are some procedure can be done such as reporting, correcting the audio/visual, selecting the report result, and structuring the writing.

Post Production. This is the last steps in making feature. It consist of editing, subtitling, and mixing.

\section{B. Research Design}

This researchis a research and development (R\&D) study. The purpose is to design a product and procedures. Gall, Gall, and Borg (2003) defines educational Research and Development $(R \& D)$ study as the industry-based development model which the findings of the research are used to design new products and procedures.

This R\&D study produces a model feature radio that is used as a guidance in producing feature. The development procedureis adapted and modified the ones proposed by Dick, Carrey, and Carrey (2001) and Lee and Owen (2004). Therefore, the development procedures of this research and development were as follows:

\section{Needs Analysis}

The needs analysis of this research were taken from syllabus, students opinion and radio industry about radio feature product. Based on the data, the feature radio will be developed.

Product Development

The researcher will do collaboration with two of English Department students who will make feature radio as their final pro- 
ject. The researcher will guide the students based on the appropriate steps that have been chosen before.

\section{Product Validation}

The experts' judgments were used to know whether the product was eligible. The feature radio result will be analyzed by the expert. The experts consist of the content expert to validate the feature script and the radio expert to validate the feature radio product.

\section{Product Revision}

Product revision is a process to revise the product that was assessed by the experts. In this part, the assessments from the experts' judgments were analyzed and then it was used to revise the feature radio product. This step is important to know whether the product can be tried out.

The instrumentation that is used in this study are tape recorder, questionnaire form (for expert judgment), and students feature radio. The data were collected through observation, and the evaluation form from expert/ the professional radio broadcaster.

In analyzing the data, the researchers follow some steps. First, the researchers will give the students' feature radio to professional radio broadcaster to be evaluated. Then, based on the evaluation, the researcher will analyzed the weaknesses of those products and find the formula to improve the students' feature radio products. After that, the researchers ask the students to reproduce the better feature radio with the same topic.

\section{Result and Discussion}

There were some respondents involved in this research. First, two students of English department who took feature radio as their final project. Second, one content expert of professional radio broadcaster in Padang who gave her judgment on the content of the students' feature radio. Third, one radio broadcaster expert who gave his judgment on the quality of the product.

Since it is research and development ( $R$ and D) research, hence the researchers develop a model for feature radio based on the following steps:

\section{Need Analysis}

In this step, the researchers analyzed and identified the need of a model for feature radio for English department student of State Polytechnic of Padang through three ways. The first need analysis was analyzing the syllabus of radio broadcasting. In the syllabus, it is mentioned that Feature is one of the skill of radio broadcasting that must be master by the students. The learning outcome of the syllabus state that the students have to be able to produce a feature radio at the end of the semester. Therefore, the researcher who also as the lecturers of radio broadcasting subject asked the students to produce a feature radio at the end of the fifth semester in academic year 20162017.

The second analysis was academic data related to the final project that were conducted by English Department students. Based on the data in academic year 2014-2015, from 49 students who conducted final project, only three of them chose feature radio as their final project product. Then, in academic year 20152016 , only one students conducted final project on feature radio.

Based on the first and second analysis, then the researchers continued the analysis through interview. The first interview was conducted to some graduate students who did not choose feature radio as their final project. The interview was unstructured where the researchers want to know the reason why they did not want to choose feature radio as their final project. From the interview results, it was found that the students did not want to conduct feature radio as their final project due to there is no an appropriate guide book related to feature radio since they just can find references about feature movie and feature writing. Moreover, they also said that there is no fix model of feature radio that is available. to be refers.

The second interview was conducted to one of professional radio broadcaster in Padang who has experience in producing feature radio. This interview was aimed to know the criteria and the procedures for making a good feature radio. 


\section{Product Development}

Based on the some data gathered in need analysis, then the researcher collaborated with two English department students who chose feature radio as their final project. The researchers' role is as their advisor who guide them in producing the feature radio. The researchers guide them based on a guided book constructed based on need analysis. In producing the feature radio, there are three stages that should be followed by the students, namely; pre-production, production, and post production.

1. Pre-production. It was the first step and also sometimes become the most difficult step for the students in making the radio feature. Because pre-production determines the next steps. In the beginning, the students should find the topic for their feature. The topic can be found through reading books, googling, discussing, looking the social phenomena around them, and etc. After getting the idea for their feature radio topic, the students discussed it with their advisors (researchers).. After the topicswere approved by the advisors (researchers), thestudents did some observation to get more information and data related to the topic.After that, the students constructed the story board or frame work of the feature which consists of the topic, the aims, the questionslist, theinformants to be interviewed, the questions list, time table or schedule, budget estimation. In addition, they should alsodetermine the appropriate back sound and wildtracking for the feature. Finally, the students prepared some tools needed for this project such as smart phone to record the voice and interviews and laptop to save the recordings data

2. Production: After the frame work was approved by the researchers, the student started to collect the data by conducting some interviews with the informants. When the interview run, the students recorded all of the statement of the informants via their smart phone, and the interviews should be based on the questions list that have been made. Furthermore, it used to make the interview session more focus and related to the data that is want to be found. Beside recording the interview session, they also recorded the wildtracking or the sound surrounding the place of interview such as the sound of water, birdsong, traffic, children, and etc. Those sound are important and useful to make the listener feel the atmosphere of the feature directly. After all the information have gathered, the students listened all of the interview results. They started to select the best insert or the appropriate recorded to be inserted to the script. After choosing the insert, the started to write the script. In making the script, the students discussed it with their advisors related to the content and also the language. Because they are from English Department, they should use English to make the script and the narration. Then, they did the voice over (VO) or recording the script narration. They conducted the recording process at Polytechnic radio studio. The students used Cool Edit Pro (Version 2.1) application to record their voice.

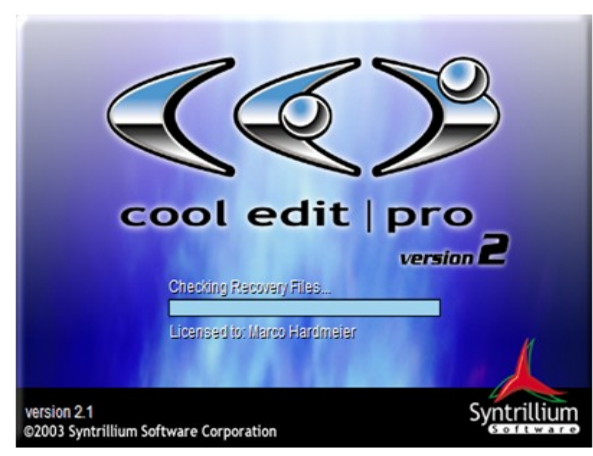

Fig.1 The Display of Cool Edit Application

Post-production: Post- production is the last step in conducting the feature radio. In this part, there are two procedure were done, namely; editing and mixing. In editing, the students used Cool Edit Pro (Version 2.1). They edited the noise and unneeded voice in order to get the best quality of the recording.

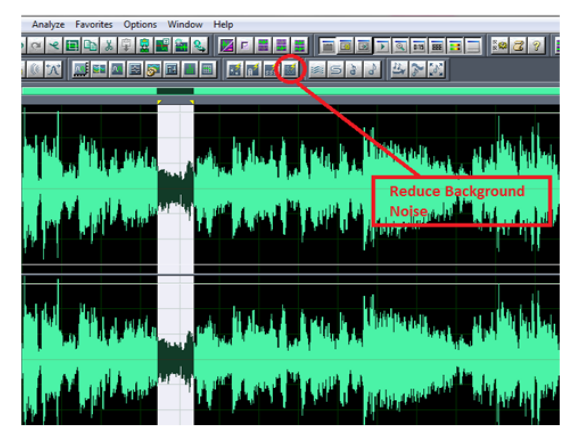

Fig. 2 Editing Process

After editing the insert, VO, wildtracking, and backsound, they continued to mixing process. It is the process to combine the insert, $\mathrm{VO}$, wildtracking, and backsound become a good order. Therefore, the feature can be 
understandable for the listener and it can be interesting to be listened. The mixing process were done by using Cool Edit Pro (Version 2.1). The process can be seen in the following figure through multitrack view.

After doing editing and mixing process, it means that the feature was ready to be given to the expert judgment. It was used to give the assessment to the feature whether it is good or need some revision. The duration of the final product of the feature is about 15 minutes.

\section{Product Validation}

The feature made by the students then gave to the expert to be judged. There were two radio broadcaster expert who analyzed the feature based on the questionnaire prepared by the researcher related to the content, delivery. Based on the questionnaire returned by the expert, it was known that the feature radio made by the students still need improvement in some aspect;

1. Content. Related to the content, the experts suggested to make the topic of the feature become more specific. Then, they suggested to add some informant to be inserted in the feature radio. In addition, there are some mistakes that were found in the script. Therefore, the experts asked the students to revise the script. Related to the script, the students first wrote it in Indonesia version, after that they translated it into English. The script in Indonesia was checked by the Expert, while the English version was checked by the advisors (researcher)

2. Delivery. Related to the delivery of the feature radio, the experts suggested the students to adjust the theme song and also the wildtrack with the topic. It was used to make the listener more get the felling and atmosphere of the feature. Based on the suggestion, the students revised and found the song, the backsound and also the wildtracking that more related to the topic.

3. Language Related to the language use, the experts suggested the students to revise the narration including the articulation, the pronunciation, the intonation, the expression and the sentence arrangement. In addition, they asked the students to synchronize the language with the script.

\section{Product Revision}

Based on the assessments and suggestions from the experts, the advisors (researcher) guided the students to make the revision of their feature. They had to revise the feature by adding some backsounds, wildtracking, narration, and etc. Then, they also have to improve their English, especially for their articulation, pronounciation, intonation, and the expression during read the narration. Finally, their final feature radio product consist 750 words for the script and audio duration is about 15 minutes.

\section{Conclusion}

Producing a feature radio that is used for the final project is not easy. The students should have a good effort to make the appropriate product that is understandable and comprehensible for the listeners. Sometimes, the lack of references and also inadequate model of feature make the students do not want to produce a feature radio. Meanwhile, the process of making radio feature is easier rather than making TV broadcasting product and the cost is also cheaper.

Moreover, to produce a good and acceptable feature radio, it needs some procedures to be followed. As general, there are three stages in producing radio feature, namely; pre-production, production and postproduction. Through those stages, it had already obtained the good and appropriate feature radio. In addition, the product can be used as the pilot and model of feature radio for English Department students of State Polytechnic of Padang in conducting their final project.

By having an appropriate and good model of feature radio, it is hoped that the number of students who chose radio feature as their final product will increase. Furthermore, by conducting this research, it can be developed the guide book for making feature radio that is more specific and useful especially for English Department students.

\section{Acknowledgement}

Alhamdulillahirabbil'alamin, thanks to ALLAH SWT, who has given us opportunity to conduct and finish this research and development (R\&D) study. This research willnot be complete without help and support from various parties. First, we would like to thanks to The Head of English Department who give 
permission and support us in conducting this project. Then, we give special gratitude to our colleague as well as our expert judgment Ms. WellyAdhia and ..... for giving us valuable comments and suggestions to make the feature radio product become better. In addition, thanks to our students, Hadi Permana and FeldiSandria, who have a good collaboration and help us in making a good model of feature radio. Finally, we would like to say thanks to our colleague in English department and all parties which cannot be mentioned one by one.

We would like to thank some people who contributed in conducting this research. First two students of English Department of state Politechnic of Padang: Feldi and Hadi who collaborated with the researcher in producing the feature radio. MsWellyAdia Causal Productions for permits to use and revise the template provided by Causal Productions. Original version of this template was provided by courtesy of Causal Productions (www.causalproductions.com).

Damas, H. S. The Radio Feature. Retrieved from http://ocw.uc3m.es/periodismo/ radio-journalism/topic-4-radio-features

d'Ecclesia, G. (2013). Theories and Techniques of Radio Broadcasting.Retrieved from info@radiobroadcaster.org

Fachruddin, A. (2014). Dasar-dasar Produksi Televisi. Jakarta: Kencana

Gall, M.D, Gall, J.P., \& Borg, W.R. (2003). Educational research an introduction (7th ed). Boston: Pearson Education, Inc.

Lee, W.W., Owen, D.L. (2004). Multimediabased instructional design. San Fransisco: John Wiley \& Sons, Inc.

Lesmana, F. (2017). Feature Tulisan Jurnalistik yang Kreatif. Yogyakarta: CV ANDI OFFSET

McLeish, R. (2005). Radio Production (5 th ed.). New York: Focal Press

Mohammed, J. (2013). Challenges and Opportunities in the Use of Radio Broadcast for Development in Ethiopia: Secondary Data Analysis. Online Journal of Communication and Media Technologies, Volume: 3 - Issue: 2 - April - 2013
Oramahi, A., H. (2012). Jurnalistik Radio Kiat Menulis Berita Radio. Jakarta : Erlangga

Prayudha, H.,H., Rustam, A. (2013) Radio is Sound Only Pengantar dan prinsip Penyiaran Radio di Era Digital. Jakarta: Broadcastmagz

Widarmanto, T. (2016). PengantarJurnalistik: PanduanAwalPenulisdanJurnalis.Indonesia: Araska. 